\title{
DESAIN KEBIJAKAN REFORMASI SISTEM PERPAJAKAN MELALUI E-TAXATION DI INDONESIA: BELAJAR PADA KEBERHASILAN REFORMASI SISTEM PERPAJAKAN DI JEPANG
}

\author{
Novy Setia Yunas \\ Program Studi Ilmu Pemerintahan Universitas Darul ‘Ulum Jombang \\ Email: novysetiayunas@gmail.com
}

\begin{abstract}
ABSTRAK
Penggunaan Teknologi dan Informasi ditengah arus globalisasi dan modernisasi yang cukup pesat merupakan prasyarat utama untuk menciptakan reformasi dalam pelayanan publik. Salah satunya adalah muncul sistem electronic government (e-gov). Dalam perkembangannya, pengejawantahan electronic government sebagai sebuah langkah praktis untuk menciptakan reformasi pelayanan publik yang lebih berorientasi pada masyarakat cukup beragam salah satunya melalui keberadaan aplikasi electronic taxation (e-tax). E-tax merupakan sistem administrasi perpajakan yang mengadopsi penggunaan teknologi, informasi dan komunikasi untuk memudahkan masyarakat sebagai wajib pajak dalam melaksanakan setiap transaksi berkaitan pajak. Makalah ini memberikan gambaran tentang perkembangan kebijakan reformasi sistem perpajakan berbasis elektronik (etax) di Indonesia berkaca pada sistem yang telah dikembangkan di Jepang. Implementasi e-tax salah satunya telah berjalan cukup maksimal di negara Jepang. Penggunaan aplikasi ini cukup memberikan dampak yang signifikan bagi peningkatan pendapatan negara dari sektor pajak, perampingan sistem birokrasi dan peningkatan kembali kepercayaan masyarakat terhadap Badan Pajak Nasional Jepang.
\end{abstract}

Kata Kunci: Kebijakan, Pajak, E-Government, E-Tax

\begin{abstract}
The use of Information technology and the current globalization and modernization in the middle of a fairly rapid is a prerequisite for creating the reform in the public service. One of them is the electronic government system appears (e-gov). In the process, the embodiment of electronic government as a practical step to create more public service reform oriented community is quite diverse one through the application of electronic taxation (e-tax). E- tax is the tax administration system that adopts the use of information and communication technologies, to facilitate the public as tax payers in carrying out any transaction related taxes. This paper gives an overview of the development of the tax system reform on policy based electronic (e-tax) in Indonesia looking at systems that have been developed in Japan. Implementation of e-tax one had walked quite a maximum in the country of Japan. The use of this application simply provide a siginificant impact for increased state revenue from tax sectors, streamlining the system of bureaucracy and increased public confidence back against Japan's National Tax Agency.

Keyword: Policy, Tax, E-Government, E-Tax
\end{abstract}




\section{PENDAHULUAN}

Globalisasi saat ini menjadi isu aktual dalam kehidupan berbangsa dan bernegara khususnya dalam konteks pergaulan internasional. Globalisasi memberikan perubahan tersendiri bagi tatanan kehidupan di berbagai negara di seluruh penjuru dunia. Melalui keberadaan globalisasi, negara- negara di dunia hidup ibarat tanpa sekat atau batasbatas penghalang yang absolut. Banyak yang melihat hal ini merupakan sebuah ekses negatif dari perkembangan globalisasi yang nantinya dapat menggerus tata nilai sosial dan budaya asli yang berkembang di masing- masing negara. Namun di sisi lain, globalisasi memberikan sebuah ekses positif tersendiri, seperti arus informasi dan komunikasi yang sangat pesat bagi kehidupan masyarakat. Keberadaan globalisasi juga memiliki kaitan erat dengan modernisasi. Melalui era globalisasi tersebut, masyarakat seakan dituntut untuk menyesuaikan diri dengan kehidupan yang serba modern. Implikasi terbesar dari keberadaan serta perkembangan globalisasi dan modernisasi adalah pesatnya perkembangan teknologi, informasi dan komunikasi. Perkembangan hal tersebut dapat diibaratkan pada dua sisi mata uang yang berbeda. Bisa dibilang positif karena melalui perkembangan teknologi, informasi dan komunikasi tersebut kehidupan masyarakat semakin berkembang dengan mudah. Roes Setiyadi (2003) menyebutkan bahwa keberadaan teknologi diyakini sebagai alat pengubah.Sejarah membuktikan evolusi teknologi selalu terjadi sebagai tujuan atas hasil upaya keras para jenius yang pada gilirannya temuan teknologi tersebut diaplikasikan untuk memperoleh kemudahan dalam aktivitas kehidupan dan selanjutnya memperoleh manfaat dari padanya. Tetapi di sisi lain perkembangan teknologi, informasi dan komunikasi juga menimbulkan ekses negatif dimana perkembangan yang sangat pesat tersebut mampu meracuni mindset masyarakat ke arah yang kurang baik.

Tidak hanya masyarakat, pemerintah sebagai otoritas dalam kehidupan berbangsa dan bernegara pun nampaknya juga dituntut untuk menyesuaikan diri dengan kehidupan yang serba modern ini. Modernitas yang dimaksud dalam hal ini adalah mengadopsi pola- pola kehidupan modern yang berbasis teknologi dan informasi. Tuntutan untuk mengaplikasikan teknologi informasi dan komunikasi dalam rangka modernisasi bagi pemerintah inilah yang kemudian memunculkan sebuah bentuk mekanisme pemerintahan dan pelayanan publik yang berdasar pada teknologi yakni electronic government (egovernment). Keberadaan $e$ government selain sebagai salah satu 
tuntutan modernisasi dalam mekanisme penyelenggaraan pemerintahan dan pelayanan publik, e- government juga menjadi salah satu pola baru dalam proses reformasi birokrasi yang menuntut pada penyelenggaraan pelayanan publik kepada masyarakat yang berkualitas, professional, transparan dan akuntabel. Jadi, implementasi $e$ government menjadi sebuah bagian yang terintegral dengan upaya reformasi birokrasi dan menciptakan tata pemerintahan yang baik (good governance). Sehingga pemerintah pusat dan pemerintah daerah berlomba-lomba membangun sebuah aplikasi e-government. Dalam realitanya, pengembangan aplikasi $e$ government memerlukan pendanaan yang cukup besar sehingga diperlukan kesiapan dari sisi sumber daya manusia aparat pemerintahan dan kesiapan dari masyarakat. Survei di beberapa negara menunjukkan bahwa ada kecenderungan aparat pemerintah untuk tidak melaksanakan kegiatan secara online, karena mereka lebih menyukai metode pelayanan tradisional yang berupa tatap langsung, surat-menyurat atau telepon. Kita harus belajar dari penyebab-penyebab kegagalan $e$ government di sejumlah negara yang disebabkan oleh beberapa faktor, yaitu: ketidaksiapan sumber daya manusia, sarana dan prasarana teknologi informasi, serta kurangnya perhatian dari pihak-pihak yang terlibat langsung. (Bastian, 2003)

$$
\text { E-government adalah }
$$

penggunaan teknologi informasi dan telekomunikasi untuk administrasi pemerintahan yang efisien dan efektif, serta memberikan pelayanan yang transparan dan memuaskan kepada masyarakat. Semua organisasi pemerintahan akan terpengaruh oleh perkembangan $e$ government ini. E-government dapat digolongkan dalam empat tingkatan. (Bastian, 2003) Tingkat pertama adalah pemerintah mempublikasikan informasi melalui website. Nampaknya keberadaan website resmi pemerintah merupakan sebuah hal yang wajib khusunya dalam upaya mengimplementasikan $e$ government. Melihat fungsinya, website dikelola dengan tujuan memberikan informasi seluasluasnya kepada masyarakat terkait kegiatan pemerintahan dan kebijakan- kebijakan yang telah dikeluarkan oleh pemerintah. Keberadaan website sebagai salah satu implementasi e-government merupakan bagian dari upaya membangun good governance melalui salah satu pilarnya yakni transparansi. Tingkat kedua dari implementasi $e$ - government adalah interaksi antara masyarakat dan kantor pemerintahan melaui e-mail. Ekspektasi dari keberadaan e-mail pemerintah ini adalah melalui e-mail tersebut masyarakat bisa menyampaikan kritik, saran serta 
aspirasinya kepada pemerintah untuk segera ditindaklanjuti dalam sebuah aksi nyata. Tetapi dalam tataran implementasinya, keberadaan e-mail pemerintah cenderung kurang optimal karena memang pengguna internet masih sangat rendah apalagi melihat kondisi sumber daya masyarakat yang masih banyak yang awam terhadap internet. Namun untuk mengatasinya, ada beberapa pemerintah daerah yang menggunakan sistem SMS center untuk menjembatani dan memfasilitasi masyarakat dalam proses penyampaian aspirasinya kepada masyarakat. Hal ini yang kemudian menjadi prestasi tersendiri dalam rangka menciptakan pemerintahan yang bersinergi dengan masyarakat secara baik. Tingkat ketiga adalah masyarakat pengguna dapat melakukan transaksi dengan kantor pemerintahan secara timbal balik. Untuk tingkat ketiga ini dapat diberi contoh, adanya e-procurement atau Layanan Pengadaan Secara Elektronik (LPSE). Fungsi utama dari LPSE ini antara lain menyelenggarakan pengadaan barang dan jasa pemerintah secara on-line. Melalui LPSE ini pemerintah semakin memperlihatkan bahwa transparansi dan akuntabilitas menjadi bagian penting dalam proses pengadaan barang/ jasa untuk pemerintah. Karena memang telah kita ketahui bersama bahwa proses pengadaan barang/ jasa selama ini menjadi tempat paling rawan terhadap penyelewengan. Di sisi lain, contoh dari level ke empat implemetasi $e$ - government adalah keberadaan sistem perijinan on-line. Keberadaan sistem perijinan secara on-line menjadi salah satu bentuk implementasi e-government dalam kaitannya dengan reformasi birokrasi. Selama ini masyarakat seakan dipersulit akan kebutuhan perijinan di pemerintah. Ini yang akhirnya menjadi negative image terhadap pelayanan publik di daerah. Tetapi, melalui penyediaan sistem perijinan on-line masyarakat seakan dipermudah dengan kemudahan akses melalui internet. Dan Level terakhir adalah integrasi di seluruh kantor pemerintahan, di mana masyarakat dapat melakukan transaksi dengan seluruh kantor pemerintahan yang telah mempunyai pemakaian data base bersama.

$\begin{array}{rr}\text { Selain } & \text { beberapa } \\ \text { pengembangan } & \text { electronic }\end{array}$
government yang sebagaimana dimaksud di atas, di era saat ini dikembangkan pula sebuah sistem berbasis teknologi informasi untuk kepentingan keuangan negara yakni melalui pengembangan electronic taxiation (e-tax). E- Tax merupakan sistem administrasi perpajakan elektronik dimana masyarakat diharapkan dapat memperoleh informasi mengenai pajak dan melakukan pelaporan pajak secara cepat, mudah, berjangkauan luas, dengan meminimalkan batasan ruang dan waktu, melalui jaringan internet. 
Di beberapa negara maju telah mengembangkan sistem $e$ - tax ini dengan baik. Efeknya cukup nyata yakni terjadi peningkatan yang signifikan terhadap pendapatan negara dari sektor pajak serta tingkat kepercayaan masyarakat yang cukup tinggi terhadap otoritas pengelolaan pajak.

Oleh karena itu, melalui paper ini penulis mencoba mengulas mekanisme baru dalam penyelenggaraan pemerintahan dan pelayanan publik dalam rangka reformasi birokrasi serta upaya menciptakan tata pemerintahan yang baik (good governance) melalui penggunaan sistem teknologi dan informasi sesuai dengan perkembangan globalisasi dan modernisasi yakni electronic government (e-government). Serta yang paling penting dalam makalah ini, penulis akan mengulas tentang perkembangan implementasi $e$ taxation (e-tax) di negara Jepang melalui jurnal Public Service Reform through e-Government: a Case Study of ' $e$-Tax' in Japan yang ditulis oleh Akemi Takeoka Chatfield, University of Wollongong, New South Wales, Australia. Kemudian setelah mengulas tentang perkembangan $e$ - taxation di Jepang, penulis akan mencoba memperbandingkan perkembangan implementasi $e$-tax di Indonesia dan membuat sebuah skema penerapan $e$ taxation guna semakin menyempurnakan implementasinya di Indonesia.

\section{PEMBAHASAN}

\section{Perkembangan $E$ - Tax di Jepang}

Dalam sebuah jurnal yang berjudul Public Service Reform through e-Government: a Case Study of ' $e$-Tax' in Japan, fokus penelitian terletak pada studi kasus Badan Pajak Nasional Jepang (NTA) dan inisiatif dalam implementasi $e$ government di dalamnya yang intinya terletak pada aplikasi $e$-tax. E- Tax merupakan mekanisme pajak secara online yang meliputi pengajuan, pelaporan dan layanan pembayaran pajak untuk perorangan maupun perusahaan. Berkaca dari sistem e-tax di negara lain, e-tax di Jepang berfokus pada cara untuk melayani sendiri bagi wajib pajak melalui saluran internet. Ini merupakan cara baru yang dibuat dan tersedia untuk wajib pajak perseorangan maupun perusahaan. Sistem ini bukan sebagai pengganti, tapi sebagai pelengkap cara yang masih memenuhi kepatuhan hukum pajak nasional. Dengan menggunakan sistem ini, Badan Pajak Nasional Jepang dimaksudkan untuk dapat mengubah sistem administrasi publik perpajakan yang cenderung berwajah birokrasi menjadi sebuah sistem pelayanan yang berorientasi pada kebutuhan warga negara berbasis organisasi modern, sehingga mampu 
memperoleh kembali kepercayaan warga, dan mencapai hasil-hasil kebijakan maupun kepatuhan hukum pajak yang lebih baik di negara industri global. Sejak sistem e-tax diterapkan masyarakat menganggap bahwa $e$-tax merupakan sistem yang patut dibanggakan, sehubungan penggunaan aplikasi yang lebih modern dari sistem yang sebelumnya cenderung tradisional (misalnya pengajuan pajak yang menggunakan kertas, dan tatap muka atau sekedar menelepon untuk melakukan konsultasi pelayanan pajak). Dari hasil analisa awal ini diketahui bahwa sistem $e$ - tax yang diadopsi oleh Badan Pajak Nasional Jepang mencitrakan bahwa mereka telah melakukan sebuah perubahan kinerja dan pelayanan publik ke arah yang lebih baik.

Perkembangan

implementasi $e$ - tax di Jepang tidak dapat dipisahkan dari tuntutan kepada Badan Pajak Nasional Jepang untuk melakukan sebuah reformasi terhadap sistem administrasi perpajakan secara radikal untuk mengontrol laju inflasi yang terjadi setelah perang Jepang. Kemudian Badan Pajak Nasional Jepang menerapkan sistem self assessment yang diadopsi dari negara Amerika. Namun dalam perkembangannya penerapan sistem self-assessment yang merujuk pada negara Amerika tersebut, bagaimanapun menciptakan kebingungan di kalangan usaha kecil dan menengah yang tidak memiliki pengetahuan yang cukup tentang akuntansi dan perpajakan. Karena itu, sekitar 70 persen dari wajib pajak menjadi sasaran koreksi atau penentuan untuk non-filing di bawahpengajuan pengembalian pajak penghasilan (Usui 2002). Tanggapan birokrasi yang tidak efisien dalam menangani kekacauan publik dan masalah administrasi lebih lanjut memberikan kontribusi terhadap hilangnya kepercayaan dari wajib pajak kepada kantor administrasi pajak.

Setelah mengalami permasalahan tersebut, Kemudian Badan Pajak Nasional Jepang memutuskan untuk memperkenalkan metode konsultasi pajak back office, yang tetap digunakan sampai saat ini (NTA, 2007). Metode tersebut dimaksudkan untuk menyediakan platform bagi layanan konsultasi yang diperlukan oleh pembayar pajak untuk mengajukan pembayaran pajak mereka secara sukarela dan benar. Prosedur atas metode baru tersebut melibatkan langkah-langkah berikut:

1. Petugas pajak meminta wajib pajak yang kategori bisnis untuk datang ke kantor Badan Pajak Nasional Jepang pada tanggal dan waktu yang telah ditentukan;

2. Petugas Pajak menjawab pertanyaan para wajib pajak tentang prosedur perhitungan, akuntansi 
Vol.4, No.1, April 2018

perpajakan atau yang berkaitan dengan undangundang pajak. Kemudian mereka melakukan penghitungan atas pajak pendapatan mereka;

3. Jika wajib pajak telah memahami dengan benar, pegawai pajak kemudian menjelaskan pada mereka tentang bagaimana mengisi formulir setoran pajak atas nama mereka (Usui 2002).

Ide di balik metode

konsultasi pajak baru ini adalah untuk menghilangkan pengaruh pemerintah dan ketergantungan pembayar pajak pada Badan Pajak Nasional Jepang dengan mendorong wajib pajak self-service dalam mengajukan pengembalian pajak penghasilan. Sedangkan metode konsultasi pajak baru ini dimaksudkan untuk meningkatkan self-service, dibutuhkan pembayar pajak untuk mengunjungi kantor lokal Badan Pajak Nasional Jepang untuk konsultasi, sering beberapa kali kunjungan, untuk mengajukan pengembalian pajak pendapatan nasional mereka. Namun dalam perkembangannya metode ini pun dirasa kurang efektif, karena metode konsultasi pajak baru memakan waktu dan pembayar pajak diminta untuk menunggu dalam antrian panjang, biaya kepatuhan wajib pajak cukup besar, terutama bagi pemilik usaha perusahaan ukuran kecil dan menengah yang mendominasi perekonomian sektor swasta Jepang. Karena itu, ditengah jumlah wajib pajak yang semakin meningkat disertai dengan pertumbuhan ekonomi yang makin mapan maka Badan Pajak Nasional Jepang dihadapkan pada sebuah tantangan untuk melakukan efisiensi dalam sistem administrasi perpajakan.

Untuk menjawab tantangan terhadap efisiensi dan perbaikan sistem administrasi perpajakan di Jepang, pada tahun 2003 Badan Pajak Nasional Jepang menganggarkan uang sebesar $¥ 50$ milliar untuk pembangunan software dan aplikasi electronic taxation (etax). Keberadaan e-tax dimaksudkan untuk secara radikal meningkatkan efisiensi sistem administrasi perpajakan di kedua manajemen administrasi perpajakan, baik back office maupun konsultasi pajak di bagian depan yang secara signifikan akan mengurangi biaya kepatuhan pajak masyarakat. Selain itu keberadaan $e$-tax memberikan manfaat ganda bagi baik internal (administrator pajak Badan Pajak Nasional Jepang dan garis depan konsultan pajak) serta para pemangku kepentingan eksternal dalam hal ini wajib pajak. Implementasi $e$ - tax ini dimaksudkan sebagai komitmen dalam memberikan layanan yang lebih nyaman bagi masyarakat dan mengatur operasi administrasi yang lebih simple, efisien, dan transparan 
dengan dengan memanfaatkan teknologi informasi dalam pelayanan kepada masyarakat. Hal ini pun sesuai dengan blue print penerapan sistem informasi dan teknologi dalam sistem administrasi pemerintahan di semua instansi pemerintahan di Jepang.

Implementasi e-tax di

Jepang ini dibangun melalui sebuah website yang dikelola secara transparan oleh Badan Pajak Nasional Jepang. Website e-tax ini juga terintegrasi dengan website pemerintah pusat. Sehingga melalui portal pemerintah pusat, wajib pajak dapat melakukan proses dengan satu klik saja. Kemudian setelah masuk dalam beranda website $e$-tax milik Badan Pajak Nasional Jepang, masyarakat dapat mengakses laporan kinerja Badan Pajak Nasional Jepang yang telah diaudit, laporan tahunan, komentar publik, informasi lembaga dan statistik serta hukum pajak nasional maupun perkembangan implementasi e-government yang baru. Serta yang paling penting melalui website $e$-tax tersebut, masyarakat dapat mengakses fungsi transaksional secara online, seperti mendaftar nomor pokok wajib pajak, mempersiapkan pengembalian pajak penghasilan individu dan korporasi secara online, mendapatkan peta berbasis penilaian properti secara online melalui sistem informasi geografis (GIS) dan membayar semua jenis pajak secara online melalui link langsung ke bank secara online oleh wajib pajak. Melalui website tersebut, wajib pajak dapat memenuhi kewajiban pajak nasional mereka di mana saja dan kapan saja sesuai dengan kenyamanan mereka tanpa mengunjungi dan menunggu dalam antrian panjang di kantorkantor Badan Pajak Nasional Jepang. Bagi mereka yang tidak memiliki komputer sendiri, Badan Pajak Nasional Jepang menyediakan komputer dan layar sentuh di setiap kantor pajak yang tersebar di daerah.

Kapasitas website $e$ - $\operatorname{tax}$ yang dikelola Badan Pajak Nasional Jepang ini cukup besar, hal tersebut terbukti bahwa selain menyediakan sistem transaksional sebagaimana dimaksud di atas, website tersebut berisi data wajib pajak yang sangat sensitif. Sehingga setiap pelanggaran keamanan akan memiliki dampak negatif pada kredibilitas administrasi pajak dan hak privasi informasi publik. Jadi, Badan Pajak Nasional Jepang membutuhkan wajib pajak untuk mematuhi standar keamanan NTA, termasuk pembelian sistem otentifikasi wajib pajak (dengan biaya sekitar $¥ 3,000$ ) dan tanda tangan digital. Selain itu, untuk memberikan informasi terhadap wajib pajak yang kurang mengetahui hal itu disediakan kurva belajar yang tidak terlalu rumit agar mereka mampu membiasakan diri menggunakan $e$-tax.

\section{Dampak penggunaan sistem $\boldsymbol{E}$ - Tax di Jepang}




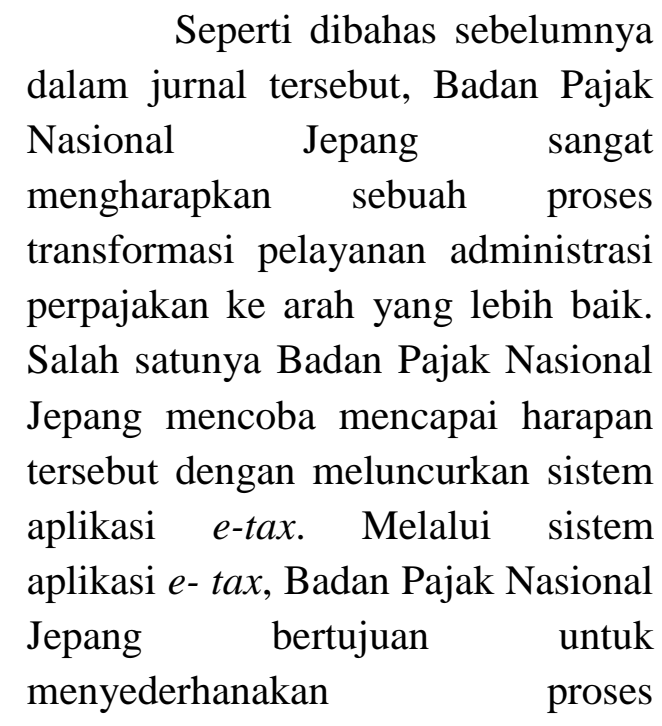
administrasi pajak yang masih ada dan membuat kepatuhan hukum pajak nasional lebih nyaman. Keberhasilan pelaksanaan e-tax menghasilkan dua manfaat utama: (1) mengurangi biaya administrasi pajak, dan (2) mengurangi biaya kepatuhan wajib pajak. Pertama, peluncuran e-tax juga memungkinkan para wajib pajak untuk menyerahkan pajak penghasilan dan pembayaran pajak melalui internet sebagai data digital, yang kemudian ditransfer, diolah dan dikelola oleh sistem manajemen yang dimiliki oleh Badan Pajak Nasional Jepang. Integrasi teknologi antara sistem $e$-tax berbasis web dan sistem informasi internal yang terpusat dimungkinkan untuk membangun jaringan petugas, konsultan pajak di bagian depan (front office) yang terdapat di kantor, dan pembayar pajak untuk berbagi informasi melalui pencatatan digital, daripada pajak yang menggunakan kertas dan lainnya yang berupa formulir pajak. Sebagai konsekuensinya, Badan Pajak Nasional Jepang harus dapat melakukannya lebih efisien dengan mengurangi waktu. Perlu dicatat bahwa peningkatan laju kinerja yang dilakukan oleh Badan Pajak Nasional Jepang direalisasikan dalam lingkungan operasional yang menantang. Melalui sistem aplikasi e-tax, Badan Pajak Nasional Jepang mampu merampingkan staf yang ada di dalamnya. Selama bertahuntahun Badan Pajak Nasional Jepang memiliki beban kerja yang makin meningkat. Jumlah pajak yang diajukan meningkat dari 7,3 juta pajak penghasilan 1975 sampai 23,5 million pada tahun 2007. Di sisi lain, jumlah karyawan kantor pajak setempat dirampingkan dari 44.171 pada tahun 2004 menjadi 43.870 pada tahun 2007. Kedua, peningkatan efisiensi operasional Badan Pajak Nasional Jepang ini diuntungkan pembayar pajak: mereka menerima respon cepat untuk setiap pertanyaan pajak yang mereka ajukan dan pelayanan konsultasi pajak yang lebih konsisten di semua kantor pajak lokal didistribusikan ke seluruh Jepang. Sistem aplikasi e-tax merupakan pilihan channel yang diaktifkan untuk mengurangi masalah kemacetan di kantor pajak daerah dan mengurangi ketidakpuasan wajib pajak dengan pelayanan pajak yang dilaksanakan Badan Pajak Nasional Jepang. 
Di sisi lain, keberadaan sistem aplikasi e- tax mampu secara signifikan meningkatkan pendapatan nasional dari sektor pajak. Terbukti pada tahun anggaran 2007, Badan Pajak Nasional Jepang berhasil mengumpulkan $¥ 53,5$ trillion pendapatan pajak nasional, yang mewakili $64,5 \%$ dari $¥ 82,9$ trilliun jumlah pendapatan nasional Jepang. Hal ini kontras dengan ¥ 43,8pendapatan pajak nasional di tahun anggaran 2002.

Melihat berbagai dampak yang telah dihasilkan dari sistem aplikasi $e$ - tax ini menunjukkan bahwa telah terjadi sebuah transformasi organisasi yang sangat signifikan di Badan Pajak Nasional Jepang. Singkatnya, keberadaan sistem e-tax di Jepang mampu mengurangi biaya administrasi pajak secara internal dan mengurangi biaya kepatuhan hukum pajak dengan memberikan pelayanan publik yang baru, nyaman, cepat, dan ditingkatkan. Selain itu, tidak bisa dipungkiri bahwa peran $e$ government mengambil bagian penting dalam proses mencapai perubahan transformasional pada kinerja administrasi publik.

\section{Perkembangan E- Tax di Indonesia}

Kunci perbaikan birokrasi yang berbelit-belit adalah perbaikan proses bisnis, yang mencakup metode, sistem, dan prosedur kerja yang jelas. Perbaikan proses bisnis merupakan pilar penting program modernisasi yang ingin dicapai oleh Direktorat Jenderal Pajak, yang diarahkan pada penerapan full automation dengan memanfaatkan teknologi informasi dan komunikasi, terutama untuk pekerjaan yang bersifat administratif. Pelaksanaan full automation ini diharapkan mampu menciptakan sebuah proses bisnis yang efisien dan efektif karena proses administrasi menjadi lebih cepat, mudah, akurat, dan paperless, sehingga dapat meningkatkan pelayanan terhadap Wajib Pajak, baik dari segi kualitas maupun waktu. Proses bisnis yang dirancang sedemikian rupa dimaksudkan agar dapat mengurangi kontak langsung antara pegawai Direktorat Jenderal Pajak dengan Wajib Pajak untuk meminimalisasi kemungkinan terjadinya kongkalikong yang berujung pada tindakan- tindakan KKN.

Di samping itu, dari segi fungsi pengawasan internal akan lebih efektif dengan adanya built-in control system, karena siapapun dapat mengawasi bergulirnya proses administrasi melalui sistem yang ada. Langkah awal perbaikan proses bisnis adalah penulisan dan dokumentasi Standard Operating Procedures (SOP) untuk setiap kegiatan di seluruh unit Direktorat Jenderal Pajak. Setidaknya Direktorat Jenderal Pajak telah meluncurkan 8 layanan unggulan bagi masyarakat yang didalamnya 
terdapat janji waktu pelayanan, kejelasan persyaratan dan prosedur. Perbaikan proses bisnis juga dilakukan antara lain melalui pemanfaatan teknologi informasi dan komunikasi (TIK) dengan dibukanya fasilitas e-filling (pengiriman SPT secara online melalui internet), $e$ payment (Modul Penerimaan Negara), dan e-registration (pendaftaran NPWP secara online melalui internet). Semua fasilitas tersebut disediakan untuk memudahkan Wajib Pajak dalam melaksanakan kewajiban perpajakannya tanpa terkendala selama 24 jam sehari dan 7 hari seminggu termasuk hari libur. Di samping itu, untuk sistem administrasi internal saat ini terus dilakukan pengembangan dan penyempurnaan Sistem Informasi Direktorat Jenderal Pajak (SIDJP). Salah satu fitur penting sistem tersebut adalah keberadaan case management dan workflow system yang digunakan untuk menyajikan informasi dan memonitor waktu dan status tahapan pekerjaan sejak mulai diterima sampai selesai. Sistem informasi manajemen internal seperti Sistem Kepegawaian, Keuangan dan Aset, Sistem Pelaporan, dan Key Performance Indicator (KPI) juga terus dikembangkan. Untuk kegiatan penegakan hukum, dikembangkan program pemeriksaan berbasis analisis risiko (risk analysis), sehingga sumber daya yang ada dapat secara efektif melakukan pemeriksaan berdasarkan skala prioritas dengan membuat segmentasi risiko yang dihadapi.

Untuk menerapkan keadilan bagi seluruh Wajib Pajak dan besarnya potensi yang dapat digali, maka Direktorat Jenderal Pajak meluncurkan program penggalian potensi Wajib Pajak non-filler, yaitu Wajib Pajak yang tidak memasukkan SPT. Masih dalam rangka penegakan hukum, Direktorat Jenderal Pajak juga mengembangkan sistem yang dapat menghimpun berbagai data dari pihak ketiga yang terkait dengan tugas Direktorat Jenderal Pajak dalam menghimpun penerimaan negara, yang dinamakan Third Party Data Project. Di samping itu, untuk mengoptimalkan efisiensi dan efektiftas fungsi penagihan, Direktorat Jenderal Pajak mengembangkan dan melaksanakan program Debt Management Project. Perbaikan proses bisnis juga dilakukan oleh Direktorat Jenderal Pajak dengan menyederhanakan formulir SPT Tahunan Pajak Penghasilan, khususnya SPT PPh Orang Pribadi dan SPT Masa PPN yang lebih memudahkan dalam pengisian oleh Wajib Pajak selain memungkinkan untuk dilakukan pemindaian (scanner friendly) pada KPPDDP. Penyederhanaan formulir SPT tersebut untuk formulir SPT 1770 S bagi Wajib Pajak yang memperoleh penghasilan dari satu atau lebih pemberi kerja dan menerbitkan formulir SPT 1770 
Sangat Sederhana (1770 SS) bagi Wajib Pajak yang memperoleh penghasilan hanya dari satu pemberi kerja dengan penghasilan setahun tidak melebihi Rp 48 juta. Seiring dengan perkembangan dunia usaha, Direktorat Jenderal Pajak telah menyesuaikan administrasi perpajakannya dengan menerbitkan template SPT bagi Wajib Pajak yang berbahasa inggris untuk memudahkan pengisian dan pencetakan SPT yang menghasilkan SPT yang sudah terisi baik dalam bahasa indonesia maupun bahasa inggris. Upaya Direktorat Jenderal Pajak untuk menyederhanakan proses pendaftaran bagi Wajib Pajak dalam rangka mendukung perbaikan iklim investasi, antara lain dengan mempermudah persyaratan pendaftaran Wajib Pajak dan Pengukuhan Pengusaha Kena Pajak terutama bagi orang asing dengan tidak mewajibkan Surat Keterangan Domisili, diganti dengan cukup hanya menyampaikan Surat Pernyataan. Direktorat Jenderal Pajak juga telah membuat kebijakan konseling bagi Wajib Pajak untuk membantu Wajib Pajak memahami ketentuan perpajakan sebagai tindak lanjut dari Surat Himbauan yang diterbitkan oleh Kantor Pelayanan Pajak, dan diharapkan pada masa yang akan datang hal tersebut akan mendorong Wajib Pajak menjadi patuh secara suka rela.

Selain itu, dalam upaya untuk memberikan kemudahan kepada masyarakat, khususnya dalam rangka memenuhi kewajiban Pajak Bumi dan Bangunan yang sangat dirasakan oleh masyarakat luas, Direktorat Jenderal Pajak melanjutkan dan memperluas kerja sama Tempat Pembayaran Elektronik. Tempat Pembayaran Elektronik ini merupakan fasilitas pembayaran Pajak Bumi dan Bangunan yang dapat dilakukan di ATM/teller, dan fasilitas lain yang disediakan oleh bank-bank yang telah melakukan kerjasama dengan Direktorat Jenderal Pajak. Dengan fasilitas ini Wajib Pajak dapat melakukan pembayaran PBB tanpa terkendala selama 24 jam sehari dan 7 hari seminggu termasuk hari libur, dan akan memperoleh bukti pembayaran yang berbentu struk ATM atau bukti pembayaran lain yang dikeluarkan oleh bank. Struk tersebut dapat digunakan Wajib Pajak sebagai bukti pembayaran PBB yang sah pengganti Surat Tanda Terima Setoran (STTS). Dari sisi administrasi perpajakan, fasilitas ini memperbaiki komunikasi data pembayaran PBB antara Direktorat Jenderal Pajak dengan bank, dengan menggunakan jaringan real time online sehingga dapat menyajikan data pembayaran secara cepat dan akurat. Hal lain yang telah dilakukan Direktorat Jenderal Pajak dalam rangka tertib administrasi dan penyederhanaan proses pengawasan internal serta mempercepat proses pengambilan keputusan oleh 
pimpinan, adalah menetapkan standarisasi dan penyederhanaan sistem pelaporan rutin di lingkungan Direktorat Jenderal Pajak. Tujuannya untuk mengurangi beban administrasi bagi unit operasional tanpa mengurangi kebutuhan pengawasan dan monitoring.

Modernisasi teknologi komunikasi dan informasi yang dilakukan Direktorat Jenderal Pajak mulai tahun 2007 meliputi kegiatan penyusunan blueprint IT. Penyelesaian tahap persiapan penyusunan blueprint IT ditandai dengan telah terkumpulnya bahanbahan yang diperlukan dalam penyusunan draft blueprint IT tersebut. Kegiatan penyusunan blueprint IT sendiri yang direncanakan pada tahun 2008 akan dilanjutkan oleh proyek PINTAR (Project for Indonesian Tax Administration Reform). Di samping itu juga telah diselesaikan tahap persiapan untuk pelaksanaan audit sistem informasi yang direncanakan akan dilaksanakan pada tahun 2008 . Dalam rangka melakukan tertib administrasi dan penyederhanaan proses pengawasan internal Direktorat Jenderal Pajak, serta mempercepat proses pengambilan keputusan oleh pimpinan, ditetapkan standarisasi dan penyederhanaan sistem pelaporan rutin di lingkungan Direktorat Jenderal Pajak sehingga dapat mengurangi beban administrasi bagi unit operasional tanpa mengurangi kebutuhan pengawasan dan monitoring.

Upaya pemeliharaan sistem yang telah diimplementasikan difokuskan pada hal-hal yang masih menjadi tantangan yaitu perbaikan performance dari sistem informasi antara lain dengan memperkuat infrastruktur dan jaringan komunikasi data serta meningkatkan optimalisasi database dan aplikasi. Selain itu, perlu ditingkatkannya system support (layanan dan dukungan teknis) dalam penyelesaian permasalahan-permasalahan teknis (troubleshooting) yang terjadi. Dengan perbaikan atau penyempurnaan system tersebut diharpkan aplikasi akan menjadi lebih sederhana, akses menjadi lebih cepat, beban terhadap basis data dan jaringan berkurang, optimalisasi infrastruktur teknologi informasi, serta peningkatan system pendukung dalam penyelesaian masalah yang terjadi. Faktor pendukung yang sangat dibutuhkan adalah sumber daya yang cukup dari sisi kuantitas dan kualitas dengan cara menambah jumlah SDM Teknologi, Informasi dan Komunikasi pada area pengembangan sistem informasi serta area layanan dan dukungan teknis dan melakukan proses pendampingan pengembangan sistem, transfer of knowledge dan pelatihan-pelatihan.

\section{Penyempurnaan aplikasi E- Tax sebagai kebijakan}




\section{reformasi sistem perpajakan di Indonesia}

Salah satu implementasi $e$ tax di Indonesia yang diadopsi oleh Direktorat Jenderal Pajak adalah keberadaan situs www.pajak.go.id yang memuat fitur- fitur lengkap terkait electronic taxation. Dari segi tampilan

situs www.pajak.go.id secara umum cukup dinamis, terdiri dari tiga kolom seperti format yang menjadi trend dan mainstream website di era saat ini. Dilengkapi gambarflash yang di perbaharui secara periodik menjadikan tampilan muka terkesan modern dan dikelola dengan baik. Kecepatan browser untuk mengakses juga cukup ringan dan dapat berlari cukup kencang di bawah satu detik.

Penyempurnaan aplikasi $e$ tax di Indonesia diharapkan semakin baik ke depannya. Dengan berbekal NPWP sebagai username login Wajib Pajak dapat mengakses account pajak secara personal dan real time. Account personal Wajib Pajak tersebut dapat mengakses antara lain detail laporan bulanan yang telah atau belum dilaporkan, history tunggakan pajak (Surat Tagihan Pajak, Surat Ketetapan Pajak Kurang Bayar dan lain- lain yang masih menjadi tanggungan Wajib Pajak) karena dalam beberapa kasus banyak Wajib Pajak yang terlambat membayar tunggakan pajak karena pemberitahuan melalui pos yang tidak diterima atau trackrecord himbauan yang telah dikirim oleh Account Representative seperti halnya telah di rekam dalam administrasi internal (approweb) agar Wajib Pajak yang memiliki jaringan koneksi internet dapat memperoleh update info serta dapat merespon dengan cepat. Ketika Wajib Pajak membuka account pajak miliknya sendiri, maka disitu telah tersedia peringatan yang berkedip kedip alert fasilitas connection/chati ng dengan person in charge yakni account representative $(A R)$ lengkap dengan no telepon atau e-mail dari account representative yang bersangkutan. Forum tanya jawab atau konsultasi online perpajakan secara resmi juga belum diakomodasi disitus pajak tersebut. Padahal keberadaan forum tanya jawab atau konsultasi online perpajakan ini sangat dibutuhkan oleh wajib pajak yang mengalami kesulitan dalam berbagai hal misalnya penyampaian SPT, perhitungan pajak dan sebagainya.

Dalam website pajak, $e$ SPT, e-Registration, e-Filling, eNPWP, $\quad e$-Billing merupakan sederetan fasilitas elektronik yang sudah ada dalam situs pajak. Berbekal pada informasi yang diperlohe $e$-SPT PPN yang mewajibkan pelaporan melalui CSV (softcopy), banyak pelajaran berharga dilapangan yang dapat diambil sebagai bahan pembenahan 
fitur atau fasilitas lainnya. Seperti contoh konkrit berikut ini, Wajib Pajak yang tinggal di kota kecil mereka terkadang mengeluhkan pelaporan yang mengharuskan wajib pajak untuk membeli komputer atau laptop karena memang sebelumnya belum memiliki komputer, namun demikian bagi wajib pajak yang telah paham akan teknologi mereka mengharapkan fasilitas lebih dimana $e-S P T$ seharusnya dapat dikirim secara online tanpa harus datang ke Kantor Pajak atau melalui vendor ASP.

Ekspektasi serupa juga dikeluhkan para wajib pajak yang melakukan permohonan nomor seri faktur pajak. Aplikasi e-nofa dengan berbekal kode aktivasi dan password seyogyanya sudah dapat diakses melalui internet secara online. Keinginan Direktorat Jenderal Pajak untuk melakukan otomatisasi berbagai layanan telah memaksa wajib pajak untuk mengikutinya, namun pada giliran wajib pajak menuntut ekspektasi lebih maka sudah selayaknya Direktorat Jenderal Pajak dapat memenuhi harapan tersebut dengan baik.

Melanjutkan trend positif call center kring pajak 500200 yang telah memperoleh berbagai penghargaan di tingkat nasional dan internasional, situs atau website pajak masih terbuka kesempatan besar untuk berubah menjadi website yang lebih interaktif dan solutif. Di era multimedia seperti saat ini, penggunaan website harusnya memegang peran penting dalam mengedukasi serta memberi layanan online yang terkoneksi dan terotomasi secara komprehensif.

Selain pembenahan dari segi teknis layanan, yang perlu diperhatikan dalam rangka menyempurnakan aplikasi $e$-tax di Indonesia adalah informasi dan edukasi bagi wajib pajak secara luas. Karena dalam realitanya, masih banyak wajib pajak yang belum mengetahui tentang segala kemudahan yang ditawarkan berbagai fitur dari electronic taxation di Indonesia tersebut. Misalnya saja, dalam proses pendaftaran nomor NPWP masih banyak wajib pajak yang melakukan pendaftaran nomor NPWP langsung ke Kantor Pelayanan Pajak yang ada di setiap daerah. Padahal untuk memudahkan pendaftaran nomor NPWP, wajib pajak tidak harus datang ke Kantor Pelayanan Pajak melainkan cukup memanfaatkan fasilitas $e$-registration dan mengisi berbagai formulir yang telah disediakan. Setelah itu, wajib pajak tinggal menunggu waktu selama kurang lebih 2-3 minggu untuk dilakukan verifikasi oleh administrator pajak, kemudian kartu NPWP dikirimkan ke alamat rumah wajib pajak yang bersangkutan melalui kantor pos. Dari proses pelayanan seperti itu, memang ada perbedaan yang mencolok antara proses pendaftaran NPWP melalui kantor dan sistem e-registration. Jika 
melalui kantor, rata- rata wajib pajak langsung dalam sehari memperoleh kartu dan nomor NPWP. Tetapi jika melalui sistem $e^{-}$registration biasanya membutuhkan waktu yang cukup lama untuk proses verifikasi dan pengiriman kartu atau nomor NPWP oleh pos.

Masih dalam permasalahan minimnya informasi dan edukasi yang diperoleh wajib pajak terkait aplikasi $e$-tax di Indonesia, salah satu fitur dalam aplikasi e-tax di Indonesia yang kurang diketahui wajib pajak adalah $e$-billing. Aplikasi ini menawarkan kemudahan pembayaran pajak melalui metode pembayaran elektronik dengan segala kelebihannya: cepat, mudah, nyaman dan fleksibel. Meskipun penerapannya masih dalam tahap ujicoba, namun semua Wajib Pajak yang terdaftar di Kantor Pelayanan Pajak di seluruh Indonesia dapat memanfaatkan fitur layanan ini. Keberadaan e-billing sangat sesuai dengan apa yang menjadi harapan Direktorat Jenderal Pajak, para wajib pajak hanya perlu melakukan login ke layanan $e$-Billing tersebut dengan menggunakan user ID dan PIN yang telah dikirim ke email wajib pajak. Setelah berhasil login, langkah selanjutnya adalah mengisi data-data yang diperlukan. Data-data itu sama seperti yang diperlukan ketika kita mengisi SSP secara manual. Ketika semua data telah terisi, klik tombol Simpan, lanjutkan dengan tombol OK untuk memastikan data tersimpan. Ketika layar berganti, pastikan bahwa data telah sesuai, kemudian klik tombol Terbitkan Kode Billing. Kode Billing akan ditampilkan, dapat disimpan ke dalam format pdf dan dapat pula dicetak.

Setelah Kode Billing diperoleh, pembayaran dapat dilakukan melalui Kantor Pos dan bank persepsi. Penggunaan ATM maupun Internet Banking untuk pembayaran pajak dapat dilakukan dengan memasukkan Kode Billing ini, namun masih terbatas pada Bank Mandiri. Sebagai bukti pembayaran, Anda akan memperoleh Bukti Penerimaan Negara. Untuk transaksi melalui teller, bukti yang diterbitkan berupa Dokumen Bukti Penerimaan Negara. Apabila transaksi dilakukan melalui ATM, bukti transaksi berupa struk ATM, sementara apabila pembayaran dilakukan melalui Internet banking, Bukti Pembayaran yang diterbitkan dalam format elektronik yang dapat dicetak oleh Wajib Pajak. Bukti Penerimaan Negara (BPN) termasuk salinan dan fotokopinya merupakan 'sarana administrasi lain' yang kedudukannya disamakan dengan SSP. Hal tersebut diatur dalam Peraturan Pemerintah Nomor 74 tahun 2011. Sehingga dalam praktek perpajakan, untuk melakukan pelaporan surat pemberitahuan, pemindahbukuan, bukti pemotongan dan pemungutan, Bukti Penerimaan Negara tersebut mempunyai 
kedudukan hukum yang setara dengan SSP. Layanan pembayaran pajak secara elektronik melalui $e$ Billing ini merupakan perwujudan komitmen pelayanan prima Direktorat Jenderal Pajak.

Melihat permasalahanpermasalahan seperti itu, seharusnya yang perlu dilakukan oleh Direktorat Jenderal Pajak adalah pertama melakukan sosialisasi dan edukasi terhadap wajib pajak yang belum paham atau mengetahui sistem ini. Direktorat Jenderal Pajak dapat menyediakan laptop maupun komputer di setiap kantor serta tenaga untuk memberikan simulasi atau edukasi langsung kepada wajib pajak yang saat itu ada di kantor untuk melakukan berbagai transaksi. Jika hal ini dapat dilakukan maka ke depan wajib pajak akan paham dan mampu melakukannya sendiri di manapun mereka berada. Atau minimal disediakan peta simulasi di setiap fitur yang memudahkan untuk dipahami dan akan digunakan oleh wajib pajak sebagai sarana informasi dan edukasi. Kedua, perlu dibangun sistem informasi yang tangguh. Artinya, sistem informasi yang cepat dan mudah diakses adalah prasyarat utama dalam menciptakan e-tax di Indonesia karena dalam sistem tersebut data wajib pajak yang jumlahnya sangat besar juga terintegrasi di dalamnya. Ketiga, harus dibuat waktu tanggap pelayanan yang jelas. Berapa waktu yang harus dilakukan oleh administrator untuk menerima dan melakukan verifikasi data sampai dengan administrator melakukan feedback terhadap pelayanan yang dibutuhkan oleh wajib pajak. Ini perlu diatur secara jelas, jangan sampai melalui sistem online yang harusnya menyingkat waktu malah memperlama proses pelayanan karena administrator sistem tersebut tidak diberikan standar pelayanan yang jelas.

\section{KESIMPULAN}

Implementasi e-tax di Jepang telah mengalami proses yang cukup panjang sehingga berdampak cukup baik bagi keuangan negara, reformasi pelayanan publik dan kepercayaan masyarakat sebagai wajib pajak terhadap Badan Pajak Nasional Jepang. Namun tidak dapat dipungkiri dalam keberhasilan proses tersebut masih terdapat berbagai celah yang membutuhkan perbaikan di masa datang. Seperti permasalahan ketidakjelasan alur jobdesc antara konsultasi back office dan fitur- fitur dalam $e$-tax di Jepang.

Di sisi lain, melihat perkembangan $e$-tax di Indonesia masih mengalami pasang surut yang cukup nyata. Pasalnya, perkembangan e-tax di Indonesia yang sedemikian rupa ini tidak dibarengi sosialisasi dan edukasi yang cukup baik kepada masyarakat selaku wajib pajak, sehingga kemudahan layanan yang sengaja diciptakan untuk para wajib pajak 
Vol.4, No.1, April 2018

tidak mampu dirasakan oleh mayoritas wajib pajak. Hanya sebagian wajib pajak yang mengetahui dan melek informasi sajalah yang mampu memanfaatkan fitur- fitur canggih tersebut. Hal inilah yang kemudian menjadi permasalahan utama terkait implementasi e-tax di Indonesia. Sehingga Direktorat Jenderal Pajak harus segera memikirkan desain yang dapat diterima terkait masalah sosialisasi dan edukasi kepada wajib pajak terhadap fitur- fitur e-tax di Indonesia.

Berbicara mengenai penyempurnaan e-tax di Indonesia, pikiran kita pun langsung tertuju kepada segenap sumber daya yang dibutuhkan dalam e-tax tersebut. Salah satunya adalah sumber daya teknologi informasi yang cukup tangguh sangat dibutuhkan untuk pengembangan e-tax di Indonesia. Pasalnya, sistem teknologi yang dibutuhkan e-tax ke depan

\section{DAFTAR PUSTAKA}

Bastian. (2003). Perkembangan egovernment di Indonesia. Jakarta: Sinar Harapan Pers.

(2003), Inpres no. 3 tahun 2003 Panduan Kebijakan Strategi Nasional Elektronik Government

DJP-RI. (2007). Laporan Kinerja Direktorat Jenderal Pajak Republik Indonesia tahun 2007. Direktorat Jenderal diharapkan mampu menjadi sebuah sistem yang terintegrasi secara paripurna meliputi data wajib pajak yang komprehensif. Pengembangan sumber daya teknologi informasi yang cukup tangguh tersebut menjadi prasyarat utama agar kemudahan yang diharapkan melalui pengembangan aplikasi ini tidak berbalik arah menjadi sebaliknya yakni menyusahkan wajib pajak karena masalah sumber daya teknologi yang kurang baik.

Sehingga di akhir makalah ini yang perlu dicatat adalah penyempurnaan sistem e-tax di Indonesia tidak bisa lepas dari daya dan upaya dari segenap sumber daya yang ada, baik wajib pajak itu sendiri maupun internal Direktorat Jenderal Pajak Republik Indonesia. Selain itu, apa yang menjadi keberhasilan Jepang dalam mengembangkan sistem e-tax sudah selayaknya bisa diadopsi untuk penyempurnaan sistem $e$-tax di Indonesia.

Pajak Republik Indonesia: Jakarta

(2012). Annual Report Direktorat Jenderal Pajak Republik Indonesia 2012. Direktorat Jenderal Pajak Republik Indonesia: Jakarta

Setiadi, Roes. (2003). Implikasi multidimensional dari kebijakan teknologi informasi Indonesia, Makalah disajikan dalam 
Vol.4, No.1, April 2018

Dies Natalis FISIPOL UGM

Yogyakarta

Sudarto, Yudo. (2006). Egovernment dan reformasi birokrasi mепији pemerintahan yang baik. Bandung: KNTIK.

Takeoka, Akemi. (2009). Public Service Reform through eGovernment: a Case Study of ' $e$-Tax' in Japan. Journal of e-Government, 7(2) University of Wollongong: New South Wales, Australia

\section{Internet}

Traffic dan E-Tax

http://www.pajak.go.id/cont ent/article/traffic-dan-e-tax diakses pada 15 Januari 2017 pukul. 11.30 WIB 